\title{
Role of Chelated Micronutrient and their Salts for Improving Crop Production of Wheat (Triticum aestivum $\mathrm{L}$.)
}

\author{
G.M. Mathur, Suman Meena* and Anuradha \\ Department of Soil Science, Agricultural Research Station Farm, \\ Sriganganagar, Rajasthan, India \\ *Corresponding author
}

\section{A B S T R A C T}

Keywords

Chelated micronutrient, Wheat (Triticum aestivum $\mathrm{L}$.) Grain yield, Ear length.

Article Info

Accepted:

14 June 2017

Available Online:

10 August 2017
A field experiment on evaluating micronutrients chelates on wheat (Triticum aestivum L.) crop was conducted during Rabi season. The field trial was sown consequently for three years 2012-13, 2013-14 and 2014-15 at the Agricultural Research Station Farm, Sriganganagar (Rajasthan), laid out in Randomized Block Design, consisted 9 treatments with 4 replications it was observed that the best results were reported for grain yield, straw yield, thousand grain weight and ear length of wheat crop in treatment $\mathrm{T}_{2} \mathrm{Zn}$ HEDP (17\%) - $3 \mathrm{gm} /$ liters of water, maximum grain yield (49.42 q/ha), straw yield ( $83.72 \mathrm{q} / \mathrm{ha})$, thousand grain weight (41.56 gm.) and ear length (11.97 $\mathrm{cm}$.) were found to be significant. A balanced fertilization program with macro and micronutrients in plant nutrition holds the key for improving the growth and food grain production of crop.

\section{Introduction}

Wheat (Triticum aestivum L.) is an annual plant belongs to family Poaceae (Gramineae) is the most important cereal crop in the world and is the third major cereal produced in the world, following maize and rice (FAO, 2013). Wheat is cultivated since pre-historic times in the world. From all possible records, it seems that its center of origin is South Western Asia. In India it is the second important staple cereal food. As a Rabi season (winter season, sowing is done in autumn and harvesting in summer) crop, wheat played vital role in stabilizing the food grain production in the country (Hand Book of Agriculture by ICAR, 2010). Uttar Pradesh, Haryana, Punjab, Rajasthan are the major wheat producing states and accounts for almost $80 \%$ of total production in India. Wheat contains more protein [8-15\% (grain), $8-13 \%$ (flour)] than other cereals. Wheat proteins are of special significance (Yadav et al., 2010). Besides their significance in nutrition, these are principally concerned with providing the characteristic substance 'gluten', which is very essential for backers. Wheat straw is good source of feed for livestock in our country.

Wheat is grown not only in tropical and subtropical zones but also in the temperate zones. The optimum temperature range for ideal 
germination of wheat seed is $20-25^{\circ} \mathrm{C}$. For vegetative growth, $16-22^{\circ} \mathrm{C}$ is the optimum temperature. Wheat plant requires about 14$15^{\circ} \mathrm{C}$ optimum average temperature at the time of maturity. Wheat can be grown successfully in those regions where annual rainfall varies from 25 to $150 \mathrm{~cm}$. A well distributed winter rainfall of $15-20 \mathrm{~cm}$ is required for rainfed cropping. Wheat plant requires medium (50$60 \%$ ) humidity for their growth, but at the time of maturity, crop requires less humidity.

Wheat, though grown on a wide variety of soils, prefers fertile, well-drained medium textured loams to clayey loams. A good crop of wheat can also be raised in sandy loams and black soils (Hand book of Agriculture by ICAR, 2010). Soil should be neutral (6-8 pH) in reaction. Under dry conditions, heavy soils with good drainage are best owing to their better moisture retention properties. Soils with electrical conductivity of saturation extract $>6$ $\mathrm{dS} / \mathrm{m}$ and exchangeable sodium percentage $>40$ are not suitable for economical yield realization. The soil depth should be greater than $25 \mathrm{~cm}$ for wheat cultivation. The normal time for sowing of high-yielding cultivars in irrigated areas begins in early November. Usually, a seed rate of $100 \mathrm{~kg} / \mathrm{ha}$ is sufficient under favorable conditions of normal sowing. By adopting improved technology, the crop may yield 5-6 t grain and 7-8 t straw/ha from dwarf wheat varieties under irrigated conditions.

A balanced fertilization program with macro and micronutrients in plant nutrition is very important in the production of high yield with high quality products (Babaeian et al., 2012). The amount of micronutrients required by cereal crops is very small but it is essential for a healthy growth and life cycle completion. In India $47 \%$ of soils are potentially deficient in $\mathrm{Zn}, 12 \%$ in Fe, 3\% in Mn (Text Book of Soil Science by ICAR, 2014). Micronutrients are involved in numerous physiological processes that are essential for plants. Micronutrients consist of six essential elements: iron $(\mathrm{Fe})$, manganese $(\mathrm{Mn})$, zinc $(\mathrm{Zn})$, copper $(\mathrm{Cu})$, boron (B) and molybdenum (Mo) (Hand Book of Agriculture by ICAR, 2010), (Rawashdeh et al., 2015). These elements present in very small amounts in both soils and plants, but their role is regularly as important as the primary or secondary nutrients. Micronutrients such as iron, manganese and zinc have important roles in plant growth and yield of cereal crops. They are playing an important function in growth and development of plant. Actually, their necessary function in plant nutrition and rising soil productivity makes their significance ever greater. Micronutrient ( $\mathrm{Fe}, \mathrm{Zn}$, and $\mathrm{Mn}$ ) significantly improve the plants height, number of spike per plant, number of grain per spike, 1000-grain weight, grain yield, biological yield and harvest index. Micronutrients have prominent affects on dry matter, grain yield and straw yield in wheat (Cakmak et al., 2010).

Iron has many important functions in plant growth and development, such as involvement in the biosynthesis of chlorophyll, respiration, chloroplast development and improves the performance of photo systems. It is an essential part of many enzymes. Iron also participates in the oxidation process that releases energy from sugars and starches and in responses that convert nitrate to ammonium in plant. It plays an essential role in nucleic acid metabolism (Hand Book of Agriculture by ICAR, 2010; Rawashdeh et al., 2015). Mn utilized in enzyme activation, electron transport and in disease resistance (Khan et al., 2010). Zn has been a key element for getting higher yields. Zinc is important to membrane integrity and phytochrome activities. Zinc is essential for sugar regulation and enzymes that control plant growth. $\mathrm{Zn}$ is a vital element for wheat growth and it activates some enzymes such as carbonic anhydrase, dehydrogenase, proteins and peptidase (Hafeez et al., 2013). 


\section{Materials and Methods}

The experiment on evaluating micronutrients chelates on wheat was conducted during Rabi season. The field trial was sown consequently for three years in field no. 25, 38, and 25 on 05.12.2012, 20.11.2013 and 29.11.14 respectively at Agricultural Research Station Farm, Sriganganagar which is comes under zone I b of Rajasthan. The Irrigated NorthWestern Plain Zone (I b) comprises of Sriganganagar and Hanumangarh districts of Rajasthan, is located between $28.4^{0}$ to $30.3^{0} \mathrm{~N}$ latitude and $72.3^{\circ}$ to $75.3^{0} \mathrm{E}$ longitude. Total geographical area of zone I b is 2.06 million hectares in which 55 per cent of the cultivated area comes under canal command. Cottonwheat under light textured soils and paddywheat under flood plain soils are the prime crop sequences in the zone I $b$. In the canal command area Torrifluvents, Torripsamments and Calciorthids are major soil groups. In the present paper, findings of research on status of zinc and its availability, response and requirement to crops (wheat, cotton and kinnow), production system (Wheat-Cotton), carried out over a span of time at Agricultural Research Station, Sriganganagar have been summarized. Initial studies have shown zinc deficiency in both rotation and further systematic survey established varying degree of zinc deficiency in Torrifluvents, Torripsamments and Calciorthids soil group falling under zone, the deficiency of zinc is correlated with high $\mathrm{pH}$, low organic carbon content, $\mathrm{CaCO}_{3}$ content and coarser nature of these soil groups. Under low $(<0.60 \mathrm{ppm} \mathrm{Zn})$ and medium ( 0.60 to $1.20 \mathrm{ppm} \mathrm{Zn})$ status of available zinc in soils@ $24 \mathrm{~kg} / \mathrm{ha}$ and 12 $\mathrm{kg} / \mathrm{ha} \mathrm{ZnSO}_{4}$ respectively has recommended for wheat crop in Zone I b of Rajasthan (Prakash et al., 2002).

The treatment consisted of nine combination of chelated micronutrients and their salts $T_{1}$ : Control, $\mathrm{T}_{2}$ : Zn HEDP (17\%) - 3 gm/liters of water, $\mathrm{T}_{3}: \mathrm{Fe}$ DTPA $(7 \%)-3 \mathrm{gm} / \mathrm{litre}$ of water, $\mathrm{T}_{4}$ : Mn EDTA $(13 \%)-3 \mathrm{gm} / \mathrm{litre}$ of water, $\mathrm{T}_{5}$ : Multi Micronutrient $-3 \mathrm{gm} / \mathrm{litre}$ of water, $\mathrm{T}_{6}$ : Soil application $-6 \mathrm{~kg} \mathrm{Zn/ha,} \mathrm{T}_{7}$ : Zinc sulphate spray @ $0.5 \%, \mathrm{~T}_{8}$ : Iron sulphate spray @ $1.0 \%, \mathrm{~T}_{9}$ : Manganese sulphate@ @ $0.5 \%$. The trial was laid out in a randomized block design with four replications; wheat crop seed rate is 100-120 $\mathrm{kg} \mathrm{ha}^{-1}$. Raj.-1482 variety of wheat was used for sowing every year. All the agronomic practices were carried out uniformly to raise the crop. The wheat crop was harvested on 30.04.2013, 25.04.2014 and 19.04.2015, respectively. The foliar spray of chelated micronutrients and their salts of treatment protocol were given at vegetative stage and Flag leaf initiation. The $1^{\text {st }}$ spray has been done on in January every year at Vegetative stage and 2nd spray on February and March every year at Flag leaf stage accordingly sprays of Zn HEDP (17\%), Fe DTPA (7\%) and Mn EDTA (13\%) were applied on wheat crop. Similarly spray of $\mathrm{Zn}, \mathrm{Fe}$ and $\mathrm{Mn}$ through their inorganic salts and that of multimicronutrient mixture was also sprayed every year. During the course of experiment initial soil analysis data of the experimental soil were taken and these data given in table 1 . These initial soil analysis of the experimental soil (Table 1, Mean of 3 years) showed that soils were neutral normal with regard to $\mathrm{pH}$ (Av. 8.22) and electric conductivity was $0.19 \mathrm{dS}^{-\mathrm{m}}$. Soils were low in organic carbon content (Av.0.13\%) and also low in available $\mathrm{P}_{2} \mathrm{O}_{5}$ (Av. $15.52 \mathrm{~kg} / \mathrm{ha}$ ) and high in available $\mathrm{K}_{2} \mathrm{O}$ (Av. $350 \mathrm{~kg} / \mathrm{ha}$ ). The DTPA extractable $\mathrm{Zn}$ content in soil was low $0.44 \mathrm{ppm}(<0.60 \mathrm{ppm}$ critical limit) falling in deficient range of availability, similarly $\mathrm{Fe}$ content in soil was also low $3.46 \mathrm{ppm}$ ( $<4.5 \mathrm{ppm}$ critical limit) and Mn content in soil was normal $3.82 \mathrm{ppm}$ ( $<3.5 \mathrm{ppm}$ critical limit). Wheat crop data were recorded for grain, straw yield, ear length, thousand grain weights given in tables 2, 3,4 and 5 . 


\section{Results and Discussion}

Micronutrient plays an important role directly and indirectly in plant growth and crop production, like: Zinc is required for the formation of certain microbial enzymes. The metal has shown to be a specific inducer for pyruvic carboxylase in Rhizopus nigricans and of alcohol dehydrogenase. $\mathrm{Zn}$ activates enzymes carbonic anhydrase and dehydrogenase. $\mathrm{Zn}$ plays a role in photosynthesis, protein synthesis and nitrogen metabolism. $\mathrm{Zn}$ involved in auxin production in plants. Iron plays a key role in enzyme systems (Haem enzyme, catalase, peroxidase and cytrochromes). It plays an important role in photosynthesis, nitrogen assimilation. Manganese has a primary role in the tricarboxylic acid cycle in oxidation and reduction reactions. $\mathrm{Mn}$ is known to activate a wide variety of enzymes. It is involved in water splitting reaction during photosynthesis. It plays a role in photosynthetic $\mathrm{O}_{2}$ evolution, carbohydrate and protein synthesis. $\mathrm{Mn}$ is important for the growth of lateral roots by its role in cell elongation. Mn may play an important role in nitrogen metabolism. So micronutrients like $\mathrm{Zn}, \mathrm{Fe}, \mathrm{Mn}$ is very important as likes as other macro and micronutrients for plant growth and effective crop production in different ways (Text Book of Soil Science by ICAR, 2014). The results given in tables 2, 3, 4 and 5 indicate some of the important parameters of grain yield, straw yield, thousand grain weight and ear length of wheat crop.

Table.1 Initial soil characteristics of experimental field (Average of 3 Year)

\begin{tabular}{|c|c|c|c|c|c|c|c|c|}
\hline $\begin{array}{c}\text { Cropped Fields } \\
\text { ARS Farm, } \\
\text { SGNR }\end{array}$ & $\mathrm{pH}$ & $\begin{array}{c}\text { E. C. } \\
(1: 2.5)\end{array}$ & Org. C. & $\begin{array}{c}\text { Avail. } \\
\mathrm{P}_{2} \mathrm{O}_{5}\end{array}$ & $\begin{array}{c}\text { Avail. } \\
\mathrm{K}_{2} \mathrm{O}\end{array}$ & $\begin{array}{c}\text { DTPA }- \\
\mathrm{Zn}\end{array}$ & $\begin{array}{c}\text { DTPA }- \\
\text { Fe }\end{array}$ & $\begin{array}{c}\text { DTPA - } \\
\mathrm{Mn}\end{array}$ \\
\cline { 2 - 9 } & $(1: 2.5)$ & mhos/cm & $(\%)$ & $(\mathrm{kg} / \mathrm{ha})$ & $(\mathrm{kg} / \mathrm{ha})$ & $(\mathrm{ppm})$ & $(\mathrm{ppm})$ & $(\mathrm{ppm})$ \\
\hline $\begin{array}{c}\text { Mean of } 3 \\
\text { years }\end{array}$ & $\mathbf{8 . 2 2}$ & $\mathbf{0 . 1 9}$ & $\mathbf{0 . 1 3}$ & $\mathbf{1 5 . 5 2}$ & $\mathbf{3 5 0}$ & $\mathbf{0 . 4 4}$ & $\mathbf{3 . 4 6}$ & $\mathbf{3 . 8 2}$ \\
\hline
\end{tabular}

Table.2 Effect of different treatments on grain yield of wheat

\begin{tabular}{|c|c|c|c|c|}
\hline \multirow[t]{2}{*}{ Treatments } & \multicolumn{4}{|c|}{ Grain Yield (q/ha) } \\
\hline & 12-13 & 13-14 & 14-15 & Pooled \\
\hline T1: $\quad$ NP Control & 37.20 & 47.54 & 43.48 & 42.74 \\
\hline T2: Zn HEDP (17\%) - 3 gm/litre of water & 41.58 & 53.88 & 52.82 & 49.42 \\
\hline T3: Fe DTPA $(7 \%)-3$ gm/litre of water & 40.33 & 53.36 & 48.82 & 47.50 \\
\hline T4: Mn EDTA (13\%) - 3 gm/litre of water & 42.35 & 54.48 & 50.23 & 49.02 \\
\hline T5: Multi Micronutrient $-3 \mathrm{gm} /$ litre of water & 42.65 & 50.37 & 49.25 & 47.42 \\
\hline T6: $\quad$ Soil application $-6 \mathrm{~kg} \mathrm{Zn} \mathrm{/ha}$ & 44.11 & 51.00 & 47.42 & 47.51 \\
\hline T7: Zinc sulphate spray @ $0.5 \%$ & 42.42 & 53.60 & 50.28 & 48.77 \\
\hline T8: Iron sulphate spray @ $1.0 \%$ & 43.51 & 53.09 & 48.64 & 48.41 \\
\hline T9: Manganese sulphate @ 0.5\% & 42.01 & 52.83 & 49.26 & 48.03 \\
\hline Sem+- & 1.17 & 1.42 & 1.56 & 0.63 \\
\hline C.D. at $5 \%$ & 3.42 & 4.14 & 4.56 & 1.80 \\
\hline
\end{tabular}


Table.3 Effect of different treatments on straw yield of wheat

\begin{tabular}{|c|c|c|c|c|}
\hline \multirow[t]{2}{*}{ Treatments } & \multicolumn{4}{|c|}{ Straw yield (q/ha) } \\
\hline & $12-13$ & 13-14 & 14-15 & Pooled \\
\hline T1: NP Control & 76.00 & 85.00 & 55.44 & 72.15 \\
\hline T2: Zn HEDP $(17 \%)-3$ gm/litre of water & 87.11 & 98.47 & 65.57 & 83.72 \\
\hline T3: $\quad$ Fe DTPA (7\%) - 3 gm/litre of water & 75.57 & 96.46 & 60.48 & 77.50 \\
\hline T4: Mn EDTA (13\%) - 3 gm/litre of water & 75.98 & 91.68 & 65.29 & 77.65 \\
\hline T5: Multi Micronutrient $-3 \mathrm{gm} /$ litre of water & 75.33 & 102.02 & 60.3 & 79.22 \\
\hline T6: $\quad$ Soil application $-6 \mathrm{~kg} \mathrm{Zn} / \mathrm{ha}$ & 74.85 & 103.82 & 59.38 & 79.35 \\
\hline T7: Zinc sulphate spray @ $0.5 \%$ & 76.79 & 101.76 & 60.92 & 79.82 \\
\hline T8: Iron sulphate spray @ $1.0 \%$ & 76.52 & 94.89 & 63.82 & 78.41 \\
\hline T9: $\quad$ Manganese sulphate @ 0.5\% & 66.26 & 93.37 & 59.97 & 73.20 \\
\hline Sem+- & 1.57 & 3.31 & 1.69 & 2.15 \\
\hline C.D. at $5 \%$ & 4.59 & 9.66 & 4.92 & 6.40 \\
\hline
\end{tabular}

Table.4 Effect of different treatments on thousand grain weight of wheat

\begin{tabular}{|l|c|c|c|c|}
\hline \multirow{2}{*}{ Treatments } & \multicolumn{4}{c|}{ Thousand Grain Weight (gm.) } \\
\cline { 2 - 5 } & $\mathbf{1 2 - 1 3}$ & $\mathbf{1 3 - 1 4}$ & $\mathbf{1 4 - 1 5}$ & Mean \\
\hline T1: NP Control & 33.40 & 39.98 & 39.00 & 37.46 \\
\hline T2: Zn HEDP (17\%) - 3 gm/litre of water & $\mathbf{3 6 . 2 5}$ & $\mathbf{4 1 . 6 3}$ & $\mathbf{4 6 . 8 0}$ & $\mathbf{4 1 . 5 6}$ \\
\hline T3: Fe DTPA (7\%) - 3 gm/litre of water & 37.53 & 41.03 & 42.90 & 40.49 \\
\hline T4: Mn EDTA (13\%) - 3 gm/litre of water & 37.00 & 40.98 & 42.90 & 40.29 \\
\hline T5: Multi Micronutrient - 3gm/litre of water & 35.80 & 41.34 & 44.60 & 40.58 \\
\hline T6: Soil application - 6 kg Zn /ha & 37.75 & 40.74 & 41.70 & 40.06 \\
\hline T7: Zinc sulphate spray @ 0.5\% & 37.50 & 41.46 & 44.50 & 41.15 \\
\hline T8: Iron sulphate spray @ 1.0\% & 37.25 & 41.21 & 42.40 & 40.29 \\
\hline T9: Manganese sulphate @ 0.5\% & 35.20 & 41.80 & 45.70 & 40.90 \\
\hline Sem+- & 0.85 & 0.30 & 1.30 & 0.55 \\
\hline C.D. at 5\% & 2.49 & 0.88 & 3.7 & 1.47 \\
\hline
\end{tabular}


Table.5 Effect of different treatments on ear length of wheat

\begin{tabular}{|c|c|c|c|c|}
\hline \multirow{2}{*}{ Treatments } & \multicolumn{4}{|c|}{ Ear Length $(\mathrm{Cm})}$. \\
\hline & $12-13$ & 13-14 & 14-15 & Mean \\
\hline T1: NP Control & 11.53 & 12.41 & 9.4 & 11.11 \\
\hline T2: Zn HEDP (17\%) - 3 gm/litre of water & 12.25 & 13.25 & 10.4 & 11.97 \\
\hline T3: Fe DTPA (7\%) - 3 gm/litre of water & 11.83 & 12.93 & 9.8 & 11.52 \\
\hline T4: Mn EDTA (13\%) - 3 gm/litre of water & 12.25 & 12.73 & 9.7 & 11.56 \\
\hline T5: Multi Micronutrient $-3 \mathrm{gm} /$ litre of water & 12.00 & 12.61 & 10.0 & 11.54 \\
\hline T6: $\quad$ Soil application $-6 \mathrm{~kg} \mathrm{Zn} \mathrm{/ha}$ & 12.10 & 12.55 & 10.5 & 11.72 \\
\hline T7: Zinc sulphate spray @ $0.5 \%$ & 12.28 & 12.77 & 10.2 & 11.75 \\
\hline T8: Iron sulphate spray @ 1.0\% & 11.85 & 12.80 & 10.2 & 11.62 \\
\hline T9: Manganese sulphate @ 0.5\% & 11.78 & 12.91 & 10.1 & 11.60 \\
\hline Sem+- & 0.11 & 0.23 & 0.21 & 0.11 \\
\hline C.D. at $5 \%$ & 0.33 & N.S. & 0.46 & 0.32 \\
\hline
\end{tabular}

The grain yield, straw yield, thousand grain weight and ear length of wheat crop was significantly higher with spray of chelated micronutrients and salts over that of control. The maximum grain yield $(49.42 \mathrm{q} / \mathrm{ha})$ was found in the treatment $T_{2}$ that was significant but it is at par with treatments $T_{4}, T_{7}, T_{8}$ and $\mathrm{T}_{9}$. The maximum straw yield $(83.72 \mathrm{q} / \mathrm{ha})$ was found in the treatment $T_{2}$ that was significant but it is at par with treatments $\mathrm{T}_{3}$, $\mathrm{T}_{4}, \mathrm{~T}_{5}, \mathrm{~T}_{6}, \mathrm{~T}_{7}$ and $\mathrm{T}_{8}$. The maximum thousand grain weight (41.56 gm.) was found in the treatment $T_{2}$ that was significant but it is at par with treatments $\mathrm{T}_{6}$ and $\mathrm{T}_{7}$. The maximum ear length $(11.97 \mathrm{~cm}$.) was found in the treatment $\mathrm{T}_{2}$ that was significant but it is at par with treatments $T_{3}, T_{4}, T_{7}, T_{8}$, and $T_{9}$. Grain yield, straw yield, ear length and thousand grain weights of wheat crop increased significantly with the application of $\mathrm{Zn}$, chelated micronutrients and salts of micronutrients.

It was concluded from field trial that the application of $\mathrm{Zn}$, chelated micronutrients and salts of micronutrients in the experiment the treatment combination $\mathrm{T}_{2} \mathrm{Zn}$ HEDP (17\%) - 3 $\mathrm{gm} /$ liters of water, was found to be the best, in increasing grain yield (49.42 q/ha), straw yield
(83.72 q/ha), thousand grain weight (41.56 gm.) and ear length $(11.97 \mathrm{~cm}$.) of wheat crop. The treatment $T_{2}$ that was significantly higher as compared to other treatment combination.

\section{Acknowledgement}

The Authors are thankful to the Zonal Director Research, for taking their keep interest and encouragement to carry out the research work at Agricultural Research Station Farm, Sriganganagar (Rajasthan).

\section{References}

Ai-Qing, Z., Qiong-Li, B., Xiao-Hong, T., XinChun, L., and Gale, W.J. 2011. Combined effect of iron and zinc on micronutrient levels in wheat (Triticum aestivum L.). J. Environ. Biol., 32: 235239.

Babaeian, M., Tavassoli, A., Essmaeilian, Y., and Javaheri, M. 2012. Effects of Fe, Zn, $\mathrm{Mg}$ and manure on seed germination characters of barley (Hordeum vulgare) African J. Microbiol. Res., 6(46): 73027305.

Bameri, M., Abdolshahi, R., Mohammadi- 
Nejad, G., Yousefi, K., Tabatabaie, S.M. 2013. Effect of different microelement treatment on wheat (Triticum aestivum) growth and yield. Intl. Res. J. Appl. Basic. Sci., 3(1): 219-223.

Bharti, K., Pandey, N., Shankhdhar, D., Srivastava, P.C., and Shankhdhar, S.C. 2013. Improving nutritional quality of wheat through soil and foliar zinc application. Plant Soil Environ., 59(8): 348-352.

Bouis, H.E., Hotz, C., McClafferty, B., Meenakshi, L.V., Pfeiffer, W.H. 2011. Biofortification: a new tool to reduce micronutrient malnutrition. Food Nutr. Bull., 32: S31-S40.

Cakmak, I., Kalayci, M., Kaya, Y., Torun, A.A., Aydin, N., Wang, Y., Arisoy, Z., Erdem, H., Yazici, A., Gokmen, O., Ozturk, L., and Horst, W.J. 2010. Biofortification and localization of zinc in wheat grain. J. Agric. Food Chem., 58: 9092-9102.

Dang, H.R., Li., Y, Sun, X., Zhang, Y, Li. 2010. Absorption, accumulation and distribution of zinc in highly-yielding winter wheat. Agr. Sci. Chin, 9(7): 965973.

Habib, M. 2012. Effect of supplementary nutrition with $\mathrm{Fe}, \mathrm{Zn}$ chelates and urea on wheat quality and quantity. African $J$. Biotechnol., 11(11): 2661-2665.

Hafeez, B.Y., Khanif, M., and Saleem, M. 2013. Role of zinc in plant nutrition- a review. American J. Experimental Agri., 3(2): 374-391.

Jackson, M.L. 1958. Soil chemical analysis, Second edition Indian Reprint, prentice hall of India, New Delhi. pp498.

Khan, M. B., Farooq, M., Hussain, M., Shahnawaz, and Shabir, G. 2010. Foliar application of micronutrients improves the wheat yield and net economic return. Int. J. Agri. Biol., 10(336): 1560-8530.

Lindsay, W.L., and Norvell, W.A. 1978. Development of DTPA soil test for zinc, iron, manganese and copper. Soil Sci. Soc. Am. J., 42 (3): 421-428.

Piekarczyk, M., Jaskulski, D., and Galezewski, L. 2011. Effect of nitrogen fertilization on yield and grain technological quality of some winter wheat cultivars grown on light soil. Acta Scientiarum Polonorum, Agri., 10(2): 87-95.

Prakash, V., Pundhir, P., Kaul, M.K., and Yadava, D.K. 2002. An overview of agricultural research in North- Western plain zone of Rajasthan. Agri. Res. Station (R.A.U.) SGNR, 01: 6, 49.

Rawashdeh, H., and Sala, F. 2015. Foliar application with iron as a vital factor of wheat crop growth, yield quantity and quality: A Review. Int. J. Agri. Policy and Res., 3(9): 368-376.

Stepien, A., and Wojtkowiak, K. 2016. Effect of foliar application of $\mathrm{Cu}, \mathrm{Zn}$, and $\mathrm{Mn}$ on yield and quality indicators of winter wheat grain. Chilean J. Agri. Res., 76(2): 0718-5839.

Walkley and Black. 1947. Critical examination of rapid method for determining organic carbon in soils, effect of variance in digestion conditions and of inorganic soil constituents. Soil Sci., pp. 632: 251.

Wilcox. 1950. Electrical conductivity, Am. Water Work Assoc. J., 42: pp 775-776.

Yadav, R., Singh, S.S., Jain, N., Singh, G.P., and Prabhu, K.V. 2010. Wheat production in India: technologies to face future challenges. J. Agri. Sci., 2(2): 1916-9752.

\section{How to cite this article:}

Mathur, G.M., Suman Meena and Anuradha. 2017. Role of Chelated Micronutrient and their Salts for Improving Crop Production of Wheat (Triticum aestivum L.). Int.J.Curr.Microbiol.App.Sci. 6(8): 1042-1048. doi: https://doi.org/10.20546/ijcmas.2017.608.129 